\title{
Arendt e as revoluções: a república à luz do conceito de liberdade política ${ }^{77}$
}

\section{Arendt and the revolutions: the republic in the light of the concept of political freedom}

\section{João Pedro Andrade de Campos}

Doutorando em filosofia pela UFG

Resumo: Arendt não se dedicou a esmiuçar algumas das nuances históricas das Revoluções Americana e Francesa em sua obra, pois esse não era o seu objetivo, como ela mesma diz em Sobre a revolução. Outrossim, a empreitada da autora era a de se debruçar sobre os desdobramentos e implicações dos eventos em questão. Ela afirmava se interessar pelas questões iminentemente políticas ali postas. Neste artigo, iremos buscar percorrer essa indicativa proposta pela autora. Deste modo, e com a consciência de que o tema gera, ainda, grandes polêmicas, nosso recorte se dá pela perspectiva da relação entre os conceitos de liberdade política e república, tendo como fio condutor os eventos de Sobre a revolução.

Palavras-chave: Liberdade, República, Revolução.

Abstract: Arendt did not devote himself to scrutinizing some of the historical nuances of the American and French Revolutions in his

O presente artigo foi extraído, editado e revisado de nossa dissertação de mestrado defendida na Universidade Federal de Goiás e financiada com bolsa CAPES. 
work, for that was not its purpose, as she herself says in On Revolution. Moreover, the author's endeavor was to look at the developments and implications of the events in question. She claimed to be interested in the imminently political questions posed there. In this article, we will seek to go through this indicative proposed by the author. Thus, and with the awareness that the subject still generates great controversies, our focus is on the perspective of the relationship between the concepts of political freedom and the republic, having as its thread the events of On Revolution.

Keywords: Freedom, Republic, Revolution.

\section{Considerações iniciais}

Dara Hannah Arendt (2011), o sentido do termo "Revolução" Lempregado na política só veio a surgir durante o próprio curso dos acontecimentos do séc. XVIII em ambos os lados do Atlântico, sendo antes um conceito aplicado aos estudos da astronomia ${ }^{78}$. A conotação que conhecemos de revolução atrelada a uma mudança brusca e fundacional da realidade política de um determinado local não era compartilhada, inicialmente, pelos Pais Fundadores dos EUA e nem pelos revolucionários franceses. Eles possuíam, como observa Arendt, apenas uma perspectiva de que recolocariam as coisas do jeito que tinham de ser e não mudariam, substancialmente, o contexto em que viviam. Todavia, este aspecto representa, em nossa perspectiva, um momento pouco significativo em termos cronológicos, visto que a percepção pelos agentes revolucionários de que estavam

$78 \quad$ A respeito de críticas em relação ao conteúdo historiográfico de Sobre a revolução, vale a pena citar as observações de Newton Bignotto: "Transcorridas várias décadas desde sua publicação, é possível dizer que observações históricas contidas no livro tanto sobre a revolução americana quanto sobre a revolução francesa foram superadas pelos estudos publicados desde o aparecimento dos trabalhos pioneiros de Gordon Wood e de Bailyn sobre a história americana do século XVIII e de Furet sobre a França. Abordar, no entanto, o livro de Arendt a partir de um debate sobre a historiografia mais recente sobre o fenômeno revolucionário pode produzir um resultado pouco elucidativo na medida em que podemos acabar caindo na armadilha de produzir a hermenêutica de um texto de um ponto de vista que nem mesmo seu autor considerava como sendo o mais importante" (2011, p. 43). 
empreendendo algo novo foi sentida, em ambas as revoluções, de maneira inicial, a despeito do fato de que tinham nenhum ou pouco conhecimento de que estavam iniciando um teor preambular destes eventos.

Nas análises de Hannah Arendt sobre a Revolução Francesa, a autora destaca, por um lado, o papel da questão social como grande marco desta revolução e, por outro, o considera como seu ocaso. Para a autora, este é o principal elemento que irá distanciar as duas mais relevantes revoluções da modernidade, isto é, a Francesa e a Americana. As reflexões de Arendt acerca desta tópica são direcionadas, sobretudo, para se pensar o motivo pelo qual, em sua visão, a Revolução na França tenha "fracassado". A pensadora acredita que ao ser colocada em primeiro plano a solução das necessidades urgentes da população pobre e miserável na França, o movimento revolucionário se distanciou do objetivo primeiro de qualquer revolução que se pretenda exitosa, a saber, a fundação de um corpo político.

A perspectiva de Arendt sobre a fundação de um corpo político se assenta na efetividade da liberdade política - uma característica essencial na teoria política da autora, que se enraíza em tópicos como a ação e a fala no espaço público, livres de impedimentos. Por essa via, a Revolução Americana, embora não tenha adquirido as dimensões de sua análoga francesa, obteve um sucesso superior, pois conseguiu não só promover, mas assegurar a permanência de instituições e espaços destinados à manifestação de atos e palavras conjuntos no ambiente público sob a tutela de uma constituição, atribuindo direitos e deveres claros aos cidadãos.

Os encaminhamentos que propomos neste artigo, frente ao que mencionamos, buscará contrastar e explicitar as diferenças e peculiaridades que percorreram os eventos revolucionários francês e americano setecentistas. Como já mencionamos, não é o caso aqui de nos atermos aos aspectos estritamente históricos, dado que por um lado este não era o objetivo central da reflexão de Arendt e, por outro lado, este pode ser considerado um dos pontos de menor sustentação rigorosa na obra da autora. Posto isso, nos deteremos, enfim, no que tange o percurso 
teórico proposto pela autora que nos permite pensar os eventos em questão sob um olhar voltado para questões políticas relevantes, como a liberdade e fundação de uma república.

\section{Liberdade e espaço público}

A concepção de liberdade em Arendt dá-se por uma via que se sustenta no espaço público e que é, ainda, balizada pela ação em conjunto ${ }^{79}$. Seguindo por esse itinerário, as análises da autora endereçadas aos eventos revolucionários do setecentos reforçam que, para aqueles agentes revolucionários - os Pais Fundadores na América ou os Hommes de lettres no limiar da revolução na França -, a liberdade era existente apenas em público, pois "era uma realidade concreta, terrena, algo criado pelos homens para ser usufruído pelos homens", e assim, diferentemente do livre arbítrio ou da liberdade interior, não era um "dom ou uma capacidade; era a praça ou o espaço público feito pelos homens que a Antiguidade conhecia como a área onde a liberdade aparece e se faz visível a todos" (ARENDT, 2011, p. 169). Há uma distinção pontual, portanto, acerca do conceito de liberdade em Arendt, primeiramente pelo seu distanciamento das ideias de liberdade interior e também do liberum arbitrium, mas sobretudo pelo seu teor essencialmente público e político.

$79 \quad$ A distinção entre uma liberdade enraizada no princípio da política e outra ligada, sobretudo, ao que diz respeito ao corpo - seja no modo pelo qual os seres humanos se voltam para si e se acolhem na interioridade, ou na satisfação das necessidades biológicas da vida -, foi realizada também por Benjamin Constant. No seu ensaio Da liberdade dos antigos comparada à dos modernos, Constant recupera o sentido de liberdade atribuído aos povos gregos e romanos da Antiguidade, e uma nova liberdade que nasce com os homens na modernidade. Para o autor, há, basicamente, uma distinção entre estas duas concepções, a saber: "o objetivo dos antigos era a partilha do poder social entre todos os cidadãos de uma mesma pátria", enquanto que "o objetivo dos modernos é a segurança dos privilégios privados" (CONSTANT, 1985 , p. 3). A análise do autor nos vale como mais um elemento para acentuarmos a interpretação de Arendt acerca do sentido de liberdade na Antiguidade - e que, de acordo com a autora, foi uma fonte de inspiração tanto para os revolucionários americanos quanto para os franceses em suas ações iniciais. 
Podemos perceber, claramente, que a autora adota e incentiva uma perspectiva substantiva de liberdade, ou seja, algo que de fato seja tangível aos homens, não apenas enquanto desejo ou vontade, mas principalmente enquanto possibilidade e potência de ação. É possível dizer ainda que, para a existência deste tipo de liberdade acontecer, é caro um locus específico para ela, que é não outro senão o espaço público, pois, como estamos explicitando, "sem um âmbito público politicamente assegurado, falta à liberdade o espaço concreto onde aparecer" (ARENDT, 2013, p. 195). Ainda se mostra relevante apontarmos que estas considerações convergem, decisivamente, na predileção de Arendt pela Revolução Americana em detrimento da Revolução Francesa, tendo em perspectiva que a primeira buscou fundar, no seu transcurso, justamente esses espaços para que os homens pudessem aparecer, enquanto agentes livres, frente uns aos outros, levando a cabo a ideia de que "a liberdade como fato demonstrável e a política coincidem e são relacionadas uma à outra como dois lados da mesma matéria" (ARENDT, 2013, p. 195).

Evidencia-se que a esfera pública ou espaço público são, para usarmos de uma analogia cara ao pensamento de Aren$\mathrm{dt}$, o palco no qual atores realizam feitos por meio de atos e palavras, ou seja, um espaço compreendido como um "mundo artificial", pois é construído pelos homens enquanto artifício para se relacionarem em conjunto. Além disso, é no contexto público, sob a luz de instituições que salvaguardam o direito de se expressar politicamente, que os agentes não são relegados à restrição espacial de seus lares. Ora, em contraposição à concretude e à expressividade dos atos e falas vivenciadas no espaço público, a esfera privada da vida restringe a uma determinada obscuridade as ações humanas, de modo tal que ficam atadas à mera satisfação das necessidades biológicas do corpo.

Cabe notar que o exercício da liberdade política no espaço público se distancia, na perspectiva arendtiana, das necessidades biológicas da vida. Assim, remontando à Antiguidade clássica, os homens que podiam participar das coisas públicas 
estavam liberados das "dores do corpo" 80 e podiam, portanto, adentrar ao mundo comum, agindo entre seus pares. Todavia, mesmo prescindindo da libertação das necessidades vitais básicas, isto não implica em uma legítima afirmação da liberdade política e pública. Dizendo de outro modo, a etapa da libertação das necessidades biológicas pode ser um estágio que antecede o exercício da liberdade, porém, mais que isso, a plena liberdade política possui, no pensamento de Arendt, a prerrogativa de um espaço público comum aos homens. Este espaço, que pode ser entendido como um mundo politicamente organizado, é a condição para a elaboração de uma atividade livre que se faz entre agentes politicamente equânimes e que podem, portanto, ser notados por suas palavras e ações (ARENDT, 2013, p. 194).

Acentuando o que já mencionamos anteriormente, podemos observar que a libertação das necessidades da mera vida diz respeito a um dos pressupostos para que haja condições e possibilidades da prática política. Entretanto, mesmo que relacionadas, a simples liberação dos fados biológicos não resulta diretamente na garantia da liberdade política. Para que ocorra, de fato, a entrada ao cenário público de agentes que se farão notar por meio de suas ações e palavras, é cara a prerrogativa de que, portanto, existam instituições garantidoras da sobrevivência da esfera pública. Dizendo de outra maneira, para que seja efetiva a ação política, é imprescindível, e sem ressalvas, a necessidade da existência de um mundo compartilhado, entendido como espaço comum para a manifestação de discursos e ações plurais.

De posse destes elementos preliminares, podemos nos concentrar agora em um aspecto que diz respeito diretamente aos objetivos da revolução, uma vez que, para Arendt "o fim da revolução é a fundação da liberdade" (2011, p. 189). É possível dizer que, a partir das reflexões feitas em nossa exposição, a

80 Obviamente, esta questão toca em um ponto obscuro da história, a saber, a escravidão. Seja na Antiguidade ou na Modernidade analisadas por Arendt, esta tópica se encontra presente de forma velada. Não que a autora subscreva ou apenas ignore o quão importante e grave é o tema, mas sim que, para Arendt, esta questão deve ser discutida em outro âmbito, o do direito civil e não o da política propriamente dito. 
pensadora privilegia certo arquétipo de liberdade que se alinha ao conceito de liberdade positiva, pois se insere em um conjunto de elementos que visam destacar não apenas a livre restrição de movimento espacial dos agentes, mas, sobretudo, realça que diante desta liberdade política, os atores políticos estão seguros da possibilidade de terem seus atos e palavras compartilhados entre seus pares como elemento para fomentar a vida do cenário público. Assim, podemos perceber que embora o aspecto "positivo" da liberdade política esteja em evidência e salte aos olhos, há ainda a existência de características "negativas" da liberdade, ou seja, de alguns elementos relativos a não interferência nas ações dos cidadãos que estão assentadas, por consequência, nos direitos à liberdade de expressão e de associação ${ }^{81}$.

Em síntese, o itinerário explicitado até o momento evidencia que a autora traz à tona a tópica que diz respeito à fundação da liberdade política. Nosso intuito acerca destes aspectos é explicitar, agora, a vinculação entre a fundação do corpo político e a salvaguarda da liberdade no espaço público comum aos homens, através da redação de uma constituição.

Em conformidade com as diferenças das Revoluções Americana e Francesa, o modo pelo qual estas duas revoluções se direcionaram para assentar e constituir suas respectivas aspirações também se deu de modo diverso. No caso da Revolução Americana, o processo que se desenrolou na forma da Declaração de Independência e, posteriormente, da Constituição dos Estados Unidos, foi consequência direta de um longo conjunto de ações dos colonos, que naturalizaram e enraizaram um sistema mais horizontal de poder. Noutros termos, mesmo anteriormente à “(...) guerra de libertação, a luta pela independência que era a condição para a liberdade, e a constituição dos novos estados" (ARENDT, 2011, p. 189), os habitantes do Novo Mundo já vivenciavam a experiência de deliberar sobre questões comuns em conjunto, assumindo compromissos mútuos, fazendo promessas e constituindo uma nova maneira de se entender a dinâmica da noção de poder na tentativa de bus-

81 A distinção entre os elementos que dizem respeito a um aspecto positivo de liberdade e a outro negativo pode ser encontrada mais claramente em Berlin (1969). 
car uma perspectiva horizontal e mais participativa, em detrimento do que era rotineiro, por séculos a fio, nas monarquias do Velho Mundo mesmo já possuindo a experiência da tradição feudal na Inglaterra do séc. XIV com a Câmara dos Comuns e na França de Luís XIV com o Parlamento.

Seguindo por este raciocínio, podemos entender que a Revolução Americana foi precedida pelo hábito da participação pública e, portanto, emergiu em um terreno no qual já se fomentava a tomada de decisões e a participação política coletivas (ARENDT, 2011, p. 206). Nas palavras de Arendt, podemos perceber e reforçar o quanto a experiência do acúmulo político do Novo Mundo, desde o Velho Mundo Inglês, contribuiu na formação de um movimento revolucionário coeso e que teve seus fins bem delimitados na lei:

Os que receberam o poder de constituir, de elaborar constituições, eram delegados devidamente eleitos de corpos constituídos; receberam sua autoridade das bases, e, quando aderiram ao princípio romano de que a sede do poder reside no povo, não estavam pensando em termos de uma ficção e de um absoluto, a nação acima de qualquer autoridade e absolvida de todas as leis, e sim em termos de uma realidade existente, a multidão organizada cujo poder era exercido de acordo com as leis e limitado pelas leis. (2011, p. 217)

O entendimento constitucional que perpassou por entre aqueles que redigiram as constituições das colônias americanas esteve sempre muito claro, no sentido de ter sido norteado pela ideia de que "(...) a sede do poder era o povo, mas a fonte da lei viria a ser a Constituição, um documento escrito, uma coisa objetiva duradoura [...] assim jamais era um estado de espírito subjetivo, como a vontade" (ARENDT, 2011, p. 207).

Por outro lado, podemos dizer que o histórico da tradição política na França adveio de uma forma distinta. No decorrer do movimento revolucionário francês, aqueles agentes se depararam com a tarefa de romper com uma estrutura verticalizada na tomada de decisões e, por consequência, viram-se frente à vacância de um absoluto na política pelo qual se derivava o poder e a autoridade de arregimentar toda a população. Diante desse desafio, os revolucionários identificaram, quase por coincidência, que a libertação dos pobres e miseráveis de 
sua penúria diária deveria estar depositada no corpo da própria nação. Assim, ao passo que a Revolução Americana elaborou e incentivou a redação de um documento concreto, a Revolução Francesa deixou ao encargo da vontade do povo a direção final do movimento, representando posteriormente, em resumo, que "o endeusamento do povo na Revolução Francesa foi consequência inevitável da tentativa de derivar a lei e o poder da mesma fonte" (ARENDT, 2011, p. 237).

Se remetermos estas reflexões ao que dissemos anteriormente acerca do que Arendt entende por liberdade e libertação, podemos identificar uma relação entre o que se vivenciou nos dois lados do Atlântico e, assim, assumir que temos, de um lado, uma constituição alimentada (de maneira central, embora ocorra uma "mescla" dos dois conceitos) pela liberdade positiva e, no outro, uma pautada pela liberdade negativa ou libertação. No caso da Revolução Americana, a liberdade política dos colonos se deu por razões e condições estruturais pelas quais podemos dizer que, ao buscar nas assembleias constituintes a redação de uma constituição, buscou-se um meio de perpetuar aquele espírito fundacional e expandir a relação entre liberdade política e poder. Dessa maneira, com maior participação na esfera pública, as tomadas de decisões seriam fruto de um encadeamento de poder originário da participação ativa dos representantes de condados, municípios, e de outros espaços mais localizados de ação política.

Na Revolução Francesa, a derrubada do poder e da autoridade absolutos do rei, somada à sublevação do povo antes restrito aos caprichos das necessidades da vida, desenvolveu nos revolucionários a ideia de que a constituição se tratava de uma maneira pela qual poderiam, apenas, limitar as ações do governo, de modo tal que se assegurasse ao povo a tomada total do poder. Deste modo, identificou-se que a fonte da lei e do poder seriam colocadas sobre os ombros da população. Todavia, como estamos entendendo a partir da perspectiva de Arendt, a libertação do povo da miséria não é necessariamente reflexo de uma construção política, mas sim de uma força irresistível oriunda do caráter necessário e até mesmo volátil 
dos processos biológicos do corpo. Isto fez com que o que teria sido a constituição e a fundação de um novo corpo político, se transformasse apenas na busca de um livramento de algo que era necessário.

O caminho argumentativo que percorremos durante este item desempenhou a função basilar de mostrar como, no pensamento de Arendt, mesmo não atingindo o fim último da instauração e salvaguarda da liberdade política, a Revolução Francesa conseguiu fomentar pelos séculos posteriores uma série de discussões que ganharam capilaridade no terreno da questão social. Deste modo, fica clara a expressão de Arendt na qual a autora afirma que, embora a Revolução Americana tenha sido exitosa em seus objetivos, foi a Revolução Francesa que incendiou o mundo. Em nossa perspectiva, acreditamos que este fato tenha se dado pela irresistibilidade e força que a libertação desempenha, como mostraremos a seguir em nossa exposição. O que nos leva, no próximo item, a explicitar com maiores detalhes a relação entre liberdade e libertação na constituição de um corpo político.

\section{Libertação e a questão social}

O sentido de liberdade para Hannah Arendt recai de forma contundente sobre a política, sendo ambas, nesta ótica, indissociáveis. Assim, nossa pensadora recorre ao fenômeno político das Revoluções modernas - tendo como parâmetro as ocorridas na América e na França - para defender que, nos contornos destes movimentos, o que os impulsionou foi a avidez por liberdade política, ou seja, a busca pela estruturação de um espaço público no qual os homens pudessem agir em conjunto e deliberar sobre os mais variados temas e problemas que os envolvessem. Contudo, a autora elencará duas disparidades centrais entre estes dois movimentos revolucionários, a saber: (i) dada a abrupta tomada do espaço público francês pelos pobres e miseráveis, a instauração da liberdade política foi comprometida pela tentativa de se solucionar a questão social; por outro lado, (ii) no âmbito da América, apesar do contexto escravagista e da dizimação dos índios, as questões concernen- 
tes ao estatuto social não infligiram primazia à fundação de instituições públicas e políticas duradouras asseguradas pela redação de uma constituição.

As análises de Arendt sobre o contexto norte-americano, como já sugerimos, parecem suavizar o quão radical era a condição de opressão de negros e índios no cenário da Revolução Americana. O relato de Tocqueville sobre a situação de ambos os povos nos parece indicar já uma supressão de direitos e tolhimento identitário, que mais tarde Arendt irá exemplificar com o caso dos apátridas e refugiados. Todavia, parece-nos que se a autora examinasse com maior acuidade as questões descritas por Tocqueville, poderia ter enriquecido sua reflexão. Podemos ver, a seguir, que o autor de $A$ Democracia na América atenta para a similaridade na perda do enraizamento comunitário tanto dos negros escravizados quanto da população indígena:

A opressão tirou com isso, dos descendentes dos africanos, quase todos os privilégios da humanidade! O negro dos Estados Unidos perdeu até mesmo a lembrança de seu país: não ouve mais a língua que seus país falaram, abjurou a religião e esqueceu os costumes deles. Deixando assim de pertencer a África, não adquiriu porém nenhum direito aos bens da Europa; deteve-se entre duas sociedades; ficou isolado entre dois povos, vendido por um e repudiado pelo outro, não encontrando no universo inteiro senão o lar de seu amo para lhe fornecer uma imagem incompleta da pátria (TOCQUEVILLE, 2005, p. 374).

E sobre os índios, Tocqueville diz sobre a expulsão deles de suas terras:

No momento em que os índios deixaram seus campos paternos, já estavam esgotados ou reduzidos. A terra em que vão fixar sua morada está ocupada por gente que vê com inveja os recém-chegados. Atrás deles está a fome, diante deles a guerra, por toda a parte a miséria. A fim de escapar de tantos inimigos, eles se dividem. Cada qual procura se isolar para encontrar furtivamente os meios de sustentar sua existência e vive na imensidão dos desertos como o proscrito no seio das sociedades civilizadas. O vínculo social, desde há muito debilitado, rompe-se então. Para eles já não havia pátria, logo não haverá mais povo; no máximo restarão famílias; o nome comum se perde, a língua é esquecida, os traços da origem desaparecem. A nação deixa de existir. Mal vive na lembrança dos antiquários americanos e só é conhecida de alguns eruditos da Europa (2005, p. 381). 
Conforme Tocqueville relata, os indígenas na América do Norte viviam entre dois extremos bem delimitados, "tinham de destruir os europeus ou tornar-se seus semelhantes" (2005, p. 383). A última opção, de acordo com os relatos do autor, parecia ser a derradeira alternativa ou nem mesmo era colocada no plano da escolha pelos próprios índios. Careceríamos de um aprofundamento antropológico maior de nossa parte sobre o tema, mas podemos arriscar dizer que eles buscaram resistir aos reiterados ataques dos europeus por uma característica guerreira, somada à íntima liberdade que de desfrutavam desde que nasciam - por serem selvagens, do ponto de vista eurocêntrico. Segundo as observações de Tocqueville, podemos perceber que, diferentemente do que aconteceu com os negros ou em grau de proporção menor, os nativos americanos foram massacrados, pois resistiram às tentativas de assimilação à cultura dos colonizadores:

Debilitando entre os índios da América do Norte o sentimento da pátria, dispersando suas famílias, obscurecendo suas tradições, interrompendo a cadeia das lembranças, mudando todos os seus hábitos e alimentando desmedidamente suas necessidades, a tirania europeia tornou-os mais desordenados e menos civilizados do que já eram. A condição moral e o estado físico desses povos não cessaram simultaneamente de piorar, e eles se tornaram mais bárbaros à medida que eram mais infelizes. Todavia, os europeus não puderam modificar inteiramente o caráter dos índios e, com o poder de os destruir, nunca tiveram o de civilizá-los e submetê-los (2005, p. 376).

A condição dos negros era igualmente degradante e perplexa. A perplexidade que tangencia a condição deste povo, para além do fato de terem sido escravizados e em alguns casos já nascerem escravos, por terem sido comprados ainda no ventre da mãe (TOCQUEVILLE, 2005, p. 375), está inscrita no paradoxo de continuar escravo ou ganhar liberdade e não ter outra alternativa senão retornar ao estágio anterior por alguma outra via. Nas palavras de Tocqueville:

Se se torna livre, a independência muitas vezes lhe parece um grilhão ainda mais pesado que a própria escravatura; pois, no curso de sua existência, aprendeu a submeter-se a tudo, exceto à razão; e, se a razão se tornasse seu único guia, não lhe saberia reconhecer a voz. Mil novas necessidades o assediam, e faltam-lhes os conhecimentos e a energia necessários para resistir a eles. As necessidades são amos 
que cumpre combater, mas ele aprendeu apenas a se submeter e a obedecer. Chegou, então, a este cúmulo de miséria, em que o cativeiro o embrutece e a liberdade o faz perecer (2005, p. 375).

Podemos observar que a questão escravagista e a indígena no contexto da Revolução Americana tinha dimensões expressivas, das quais nem os Pais Fundadores poderiam passar ao largo. Todavia, vemos que Arendt reiteradamente atribui à questão social na Revolução Francesa o seu ocaso. Outrossim, não estamos de posse de elementos que corroboram a tese de que no contexto norte-americano tal questão também se dava como iminente?

Arendt delimita um recorte teórico pelo qual suas análises remetem ao enredo de temas relevantes, mas que não obteve status de questão a ser resolvida na opinião da população em geral no século XVIII. E, por isso, os próprios agentes revolucionários, os Pais Fundadores da América, não se viam impelidos a voltar seu olhar para essa problemática de maneira enfática e propositiva, ou seja, no sentido de buscar ações que pudessem melhorar as condições de vida destes povos, embora estivessem cientes da dimensão da questão. Diante do itinerário acima apresentado, podemos lembrar que o pensamento de Arendt é comumente alvo de críticas por parecer não levar em conta, dado o rigor que se faz necessário frente ao tema, a questão escravagista e indígena na América e, em contrapartida, ressaltar de forma demasiadamente negativa a questão social no solo francês. Apesar de acolhermos tais críticas, no âmbito desta discussão nos limitaremos a discutir a problemática inscrita no que tange a elaboração de uma constituição ${ }^{82}$ por se estreitar, diretamente, com o papel atribuído por Arendt à fundação de um novo corpo político.

Os estudos da autora dirigiram-se para as próprias ações dos homens das revoluções, sendo que estes não se detiveram no exame das condições dos escravos. Temos em evidên-

$82 \quad$ Posteriormente, iremos aprofundar esse tema, isto é, a relevância de uma constituição. Esperamos, com isso, relacionar e apresentar aspectos que possibilitem a vinculação do pensamento de Hannah Arendt à tradição republicana tendo como aporte o respaldo de uma constituição que sustente as instituições políticas e, por conseguinte, a liberdade de todo o corpo político. 
cia, por conseguinte, que Arendt não atua com total descaso acerca da tópica escravagista; em uma breve ressalva a autora busca apontar a omissão dos revolucionários americanos a esse respeito, mostrando de maneira sintética que, de fato, "[...] a ausência da questão social no cenário americano era, no final das contas, totalmente ilusória, pois a miséria sórdida e degradante estava ubiquamente presente sob a forma da escravidão e do trabalho escravo" (ARENDT, 2011, p. 106). Esta passagem de Sobre a revolução, nos permite perguntar: por que Arendt evita o tema apesar de reconhecer sua relevância? Posto isso, o que na verdade possibilitou a instauração da liberdade política - e o que é o centro da análise arendtiana - foi o fato de que na América, ao contrário da França, não havia aquela camada massiva de miseráveis tomados, então, por suas necessidades mais básicas, em destaque no palco do processo revolucionário.

Tanto o enredo social quanto os próprios recursos naturais do território americano, aliados ainda à sua natural extensão territorial, favoreceram um cenário de relativa abundância para a população em geral (ARENDT, 2018, p. 196). No conjunto destes elementos e daqueles que se seguem no percurso de nossa abordagem, poderemos mostrar que a questão social na América não desempenhou o mesmo papel que no Velho Mundo, pois não conseguiu aglutinar forças suficientes que pudessem trazer ao espaço público as inquietações das massas escravizadas e dizimadas e as necessidades vitais dessa parcela do povo reduzida à miséria. Deste modo, a busca pela libertação dos miseráveis no contexto francês, em relação à falta de recursos básicos para sua sobrevivência, mostrou-se, no rigor do termo, uma reivindicação necessária para a própria derrubada do Ancien Régime e, consequentemente, para a formação de um novo corpo político.

Na visão de José Luiz de Oliveira, há uma duplicidade na expressão "necessidade" acerca dos movimentos revolucionários que estamos colocando em pauta, e que pode nos auxiliar no entendimento do mote de cada um destes dois fenômenos da política. Para Oliveira, no pensamento de Arendt a referência ao termo necessidade não se aplica apenas ao que diz 
respeito às necessidades de satisfação corpóreas e à extrema pobreza. Para ele, há ainda "uma necessidade política que por meio da liberdade impulsiona os seres humanos para a instauração do novo", diferentemente "da necessidade biológica que reivindica do corpo humano, soluções urgentes para manter as suas condições vitais em funcionamento" (OLIVEIRA, 2007, p. 122). Certamente, podemos então compreender que este duplo movimento que circunda a tópica da necessidade envolveu de maneira contundente ambas as revoluções colocadas em evidência por Arendt. Porém, se de acordo com ela e com o que vimos até o momento a Revolução Americana encarna a necessidade inerente da condição humana de instauração de novos horizontes políticos, a Revolução Francesa se resvalou na necessidade de atender às demandas das camadas miseráveis da população e, diante disso, teve um direcionamento diferente do que a de sua correlata americana.

Se levarmos em consideração este duplo eixo, em torno do qual giram as duas hipóteses sobre o sentido de necessidade encaminhadas por Oliveira, devemos, primeiramente, compreender que para Arendt as necessidades do corpo surgem de maneira avassaladora e, desta forma, acrescidas também por seu fator de irresistibilidade não permitem espaço para a construção da liberdade. Assim, no ramo revolucionário francês, a derrocada deste movimento esteve inscrita no fato de que há uma atração arrebatadora em relação à tensão entre pobres e ricos, uma vez que "essa força devastadora pode parecer quase irresistível, pois brota e é alimentada pela necessidade da própria vida biológica" (ARENDT, 2011, p. 155). Deste modo, enquanto a Revolução Americana esteve desde o princípio alimentada pela trilha da construção e efetivação da liberdade política, a Revolução Francesa se viu diante do impasse entre a liberdade e a libertação, optando, como analisa Arendt, pela última.

Retomando diretamente o teor de irresistibilidade da questão social, torna-se evidente que o impulso inicial pela liberdade, transfigurado na libertação das camadas pobres e miseráveis de suas necessidades biológicas, levou a um fenômeno que, como dissemos, não havia antes na história surgido 
com tamanha profusão. Outrossim, é a partir da inserção do povo, le peuple, na geografia da revolução, que os contornos do movimento se transformam e a questão social adquire seu predicado político pela primeira vez (ARENDT, 2018, p. 188). O impacto das demandas sociais foi extremamente determinante para o curso da Revolução Francesa, ao ponto de se alocar em um patamar de importância superior ao do estabelecimento de uma forma de governo ou mesmo da "(...) constitutio libertatis, a fundação e a constituição da liberdade" (ARENDT, 2018, p. 189). Ainda sobre este ponto, ao citar Robespierre, Arendt nos mostra, de maneira didática, a guinada da liberdade para a libertação pela qual a revolução passara e como, desta maneira, colocou em segundo plano a escolha da forma de governo que assentaria e coroaria a fundação do novo corpo político: "A República? A Monarquia? Eu só conheço a questão social" (ROBESPIERRE apud ARENDT, 2018, p. 191). Fazendo alusão a uma imagem popular, podemos dizer que o movimento revolucionário francês, aliado à questão social, tornou-se algo de proporções descomunais e difíceis de serem controladas, do mesmo modo como é razoavelmente trabalhoso e imprudente apagar as chamas de uma fogueira com gasolina.

A questão social, portanto, é o ponto de virada da Revolução Francesa, é o que a torna assimétrica, ao longo de seu desenvolvimento, à Revolução Americana diante de muitos aspectos relevantes. Foi a partir do aparecimento da multidão de pobres, miseráveis e oprimidos à luz do dia, que se desloca o foco da "necessidade política" para a libertação das necessidades cotidianas. Neste sentido, para Arendt, os homens da revolução se depararam com uma antiga questão e que, além de recorrente, é muito cara ao vocabulário da teoria política, a saber: a liberdade em seu sentido negativo e a liberdade em seu sentido positivo ${ }^{83}$. No primeiro caso, estamos diante de um aspecto da liberdade que se ocupa da eliminação de qualquer restrição às ações dos indivíduos, seja ela de cunho político, econômico ou de direitos. Em sequência, temos o sentido positivo de liberdade, “(...) o de ser livre em seus atos, de realizar

\footnotetext{
83 Para uma perspectiva mais abrangente e aprofundada sobre isto, ver BERLIN (1969).
} 
não tanto o eu-quero, mas o eu-posso" (ARENDT, 2018, p. 184), que pode ser bem exposto no pensamento de Arendt através da compreensão da "(...) construção de um espaço no qual a liberdade poderia despontar nas palavras e atos de homens livres" (2018, p. 184).

Por essa via, vimos que há uma relação sedimentar no que diz respeito à compreensão positiva de liberdade em detrimento da mera libertação, e a redação de uma constituição para que, de fato, seja dado um segundo passo em direção ao arremate da fundação de um corpo político legítimo. Isto ainda se mostrou relevante para podermos compreender a inserção de todos estes elementos - liberdade política, fundação, constituição - na tessitura de uma trama que conflui, com efeito, no sustento de direitos.

\section{A liberdade política e o republicanismo}

Trazer para nossa discussão o que Arendt teoriza sobre o espaço público e sobre a categoria da ação parece ser oportuno, uma vez que é neste espaço que são delegadas as relações políticas entre os homens, as quais, dizem respeito ao seu relacionamento dentro de uma comunidade política. Neste sentido, nossa intenção agora é a de continuar nossa reflexão sobre as revoluções à luz da perspectiva política da liberdade, colocando em cena o espaço público por ser o habitat natural dessas expressões que caracterizam, desde a Antiguidade, o homem como um ser voltado para a política e para os assuntos da Cidade, de acordo com uma serie de tradições do pensamento político, em especial o republicanismo.

Estamos percebendo que uma República se constitui por uma série de artifícios que visam a preocupação com os bens públicos, com o interesse comum e com a formação de instituições que, apoiadas em uma Constituição, tenham a envergadura legal necessária para a proteção do corpo político contra as instabilidades provenientes de interesses escusos. Todavia, o Corpo político republicano não é erigido apenas desta maneira e continuado somente com o apoio do recurso constitucional. Mais 
que isso "o regime republicano não propõe apenas que o poder seja contido por leis e se exerça para o povo, em vista do bem comum, mas exige ainda que seja exercido, de algum modo, por todo o povo, ou ao menos em seu nome - nos casos em que se admite a representação política" (CARDOSO, 2004, p. 46-47). Nestes termos, parece-nos que o pensamento da autora se aproxima destas reflexões sobre a república ao passo em que avancemos, a nosso ver, revisitando a perspectiva de Arendt acerca dos sistemas de Conselhos, justamente por se tratar de um conjunto de elementos convergentes acerca do que seria enriquecedor para a questão da representação política em uma república.

Os Conselhos, como define Arendt em alguns momentos de sua reflexão sobre o Tesouro perdido das revoluções, são caracterizados pela formação espontânea (2011, p. 329) e por surgirem do seio das revoluções, por iniciativa popular visando à ação e à ordem (2011, p. 339). Além de percorrer os acontecimentos revolucionários do setecentos, o surgimento dos Conselhos também pode ser vislumbrado nos acontecimentos da Comuna de Paris de 1871, na Revolução Russa em 1905 e 1917, na Alemanha em 1918 e 1919 e na Revolução Húngara de 1956. Todavia, mais que explicitar como se deu o surgimento específico dos Conselhos em cada um destes contextos, nos importa ter em mente sua face republicana como foi explicitada por Arendt: "O objetivo comum era a fundação de um novo corpo político, um novo tipo de governo republicano que se basearia em 'repúblicas elementares' de tal forma que o poder central não privaria os corpos constituintes de seu poder original de constituir" (2011, p. 334). Percebe-se que os Conselhos objetivavam maior participação do povo na estrutura do governo.

Ao se remeter às preocupações de Thomas Jefferson com a estabilidade da nova república americana, Arendt nos diz que "o que ele viu como um perigo mortal para a república foi que a Constituição dera todo o poder aos cidadãos sem lhes dar a oportunidade de ser republicanos e de agir como cidadãos"; seguindo este raciocínio, "o perigo era que todo o poder fora dado ao povo em sua qualidade privada e não se estabelecera um espaço para o povo em sua qualidade de cidadania" (ARENDT, 2011, p. 318). 
A questão da atuação política é uma preocupação, como estamos percebendo, latente no pensamento de Arendt e que se alinha com um modo de se pensar a república como lugar da participação do povo no espaço público. Ademais, podemos ver a partir disso que o pleno exercício da cidadania é entendido como um direito primário, pois só no encontro da ação pública é que, de fato, se constituem os cidadãos republicanos.

Tendo em mente a argumentação que estamos pautando, uma questão parece ser pertinente para colocarmos em campo no sentido de melhor compreender as contribuições de Arendt para a tradição republicana e, assim, como a autora lança mão de elementos novos e enriquecedores para o fomento da tradição em questão. Neste sentido, quem é o cidadão da "República arendtiana"? Nas observações de Kohn, que assumimos a seguir, podemos perceber que a cidadania em Arendt é o encontro de uma via existencial e identitária, pois tão logo compreendamos que a pluralidade é uma categoria central do pensamento da autora, podemos visualizar que os cidadãos, no espaço público, se relacionam coletivamente na construção conjunta de instituições que reflitam um aspecto moral de reconhecer as diferenças dos outros como algo importante para a via pública:

Dessa forma, a "República", como marco de ação, deliberação e liberdade, conecta-se com uma forte noção de cidadania que tem um sentido existencial e compromete toda a identidade. O homem como cidadão é um ser de uma formação moral única, respeitoso das convicções dos outros. A questão é que os cidadãos se entregam à comunidade, amam as leis que ajudam a construir e geram instituições que expressam sua vontade e desejo. Portanto, a solidariedade é a virtude política cardeal e é indispensável para a ação, para a entrada em uma esfera pública que rompe as cadeias da existência privada e, assim, ilumina a "liberdade do mundo". A ação cívica é, assim, a maior experiência da Vida Boa (2005, p. 142) ${ }^{84}$.

$84 \quad$ ["De este modo, la 'República' como marco de la acción, deliberación y libertad entronca con una noción fuerte de ciudadanía que tiene un sentido existencial y compromete toda la identidad. El hombre como ciudadano es un ser de una sola formación moral, respetuoso de las convicciones de los otros. La cuestión es que los ciudadanos se entreguen a la colectividad, que amen las leyes que ayudan a construir, y que generen unas instituciones que expresen su voluntad y su deseo. Por ello, la solidaridad es la virtud política cardinal y es indispensable para la acción, para la entrada en un ámbito 
Os cidadãos de uma república, de forma geral, podem ser entendidos como aqueles agentes que fazem o corpo político se movimentar a partir de suas ações. Todavia, é importante ressaltarmos que apesar de ser sugestivo pensar que tal movimento contínuo no espaço público se deve a uma suposta uniformidade das ações políticas, na verdade esta performance é resultado de uma valorização da pluralidade neste contexto. Dizendo de outra maneira, os cidadãos de uma república devem ser marcados, de acordo com Arendt, por suas distinções de ações e palavras, que reforçam suas singularidades enquanto indivíduos, mas por outro lado fortalecem o corpo político por agirem visando sua manutenção e perpetuidade.

Pode-se dizer que, aparentemente, há uma tensão irreconciliável entre o público e o privado, entre o particular e o plural, que inviabilizaria a formação de uma comunidade republicana no pensamento de Arendt. Todavia, este parece ser exatamente um dos pontos que distanciam a autora de alguns elementos da tradição republicana, à primeira vista, mas que se vistos com mais atenção demarcam, sobretudo, um novo olhar sobre a República que não se limite ou se restrinja a pensar esse regime político apenas do ponto de vista do cidadão no espaço público como um agente isolado. Nas palavras de Kohn:

essa exigência de aceitar o pluralismo não significa, simplesmente, que há alteridade, que há algo que frustra os desejos, ambições, paixões ou objetivos que qualquer um de nós poderia ter e, portanto, que o agente, predominantemente necessário, para regular a sociedade civil deveria ser o da "liberdade negativa". É, antes, que há uma distinção singular sobre cada indivíduo humano e que todos têm direitos iguais de reconhecimento e solidariedade em relação a suas necessidades e interesses particulares. Assim, em comparação com o paradigma procedimental, hegemônico hoje, nossa autora reivindica o direito de isonomia e juízo crítico intersubjetivo como as condições específicas de possibilidade para uma conformação pluralista e participativa da esfera pública, ou seja, de uma práxis comunicativa democrática que funcione como um contrapeso e juiz

público que quiebra las cadenas de la existencia privada y de esta manera ilumina la 'libertad del mundo'. La acción cívica es, así, la experiencia más elevada de la Vida Buena."] 
avaliador do poder governamental, restringindo-o a um exercício limitado e visível de autoridade. (2005, p. 143) ${ }^{85}$

Nestes termos é que concordamos com a interpretação de Margareth Canovan segundo a qual existe, na perspectiva de Arendt, uma espécie de dialética hegeliana no espaço público que contrasta a unidade e pluralidade dos cidadãos:

O conceito de Arendt de uma república de cidadãos mantida unida por um mundo público compartilhado, no qual há espaço para que sua pluralidade apareça, é também muito diferente do ideal da tradição republicana clássica, que era comunitária ao ponto de ser sufocante. Como Hegel, Arendt tenta articular uma compreensão da política na qual a unidade e a pluralidade são combinadas dialeticamente e, como em Hegel, o que sintetiza os momentos opostos da dialética é o mundo concreto das instituições políticas (2002, p. 248. Grifo nosso.) $)^{86}$.

O ideal comunitário do qual Arendt busca se desvincular, na leitura de Canovan, nos faz remeter à descrição feita por Benjamin Constant da força dos costumes dentro das repúblicas da Antiguidade que, no entendimento do autor, fazia com que houvesse um desequilíbrio na articulação entre as coisas públicas e as privadas. Assim, "[para os] antigos, o indivíduo, $85 \quad$ ["esta exigencia a aceptar el pluralismo no significa, meramente, que existe otredad, que hay algo que frustra los deseos, las ambiciones, las pasiones o las metas que cualquiera de nosotros pudiese tener y, por lo tanto, que el agente, predominantemente necesario, para regular la sociedad civil deba ser el de la 'libertad negativa'. Se trata, más bien, de que existe una distinción singular acerca de todos y cada uno de los individuos humanos y que todos tienen iguales derechos al reconocimiento y a la solidaridad respecto de sus necesidades e intereses particulares. De allí que, frente al paradigma procedimentalista, hegemónico en nuestros días, nuestra autora reivindica el derecho a la isonomía y la capacidad de juicio crítico intersubjetivo como las condiciones de posibilidad específicas para una conformación pluralista y participativa de la esfera pública, es decir, de una práxis comunicativa democrática que opere como contrapeso y juez evaluador del poder gubernamental, constriñéndolo a un ejercicio limitado y visible de la autoridad."]

$86 \quad$ ["Arendt's concept of a republic of citizens held together by a shared public world in which there is space for their plurality to appear is also very different from the ideal of the classical republican tradition, which was communitarian to the point of being stifling. Like Hegel, Arendt tries to articulate an understanding of politics in which unity and plurality are dialectically combined, and, as with Hegel, what synthesises the opposed moments of the dialectic is the concrete world of political institutions."] 
quase sempre soberano nas questões públicas, é escravo em todos seus assuntos privados" (CONSTANT, 1985, p. 1). Para Constant, na Antiguidade a liberdade se definia por uma submissão dos assuntos privados ao corpo público. Já sobre a liberdade dos modernos, o autor a define, em síntese, como a não obrigação da atividade política direta na Cidade e, sobretudo, como a não interferência na vida privada: "A independência individual é a primeira das necessidades modernas. Consequentemente, não se deve nunca pedir seu sacrifício para estabelecer a liberdade política" (CONSTANT, 1985, p. 4).

Na visão de Constant, como também na de Arendt, encontramos uma convergência no que diz respeito ao modo pelo qual os autores pensam a importância de nutrir as experiências humanas tanto na esfera privada, quanto na esfera pública. Todavia, diferentemente de Constant, que tece elogios ao sistema representativo como uma alternativa para a não obrigatoriedade da atividade pública, Arendt não encaminha sua reflexão nestes mesmos contornos, pois, como estamos vendo, para ela é não só importante que os cidadãos exerçam protagonismo nas decisões públicas, mas sim, é algo substancial e constitutivo da república e, por conseguinte, da formação republicana das pessoas. Ainda nesse mesmo sentido, outra diferença relevante a ser salientada é aquela que diz respeito a crítica de Arendt ao liberalismo por se tratar de uma corrente de pensamento, à qual Constant é associado, que tenta apartar a política do espaço público estabelecendo, portanto, uma liberdade da política e, deste modo, tal corrente se dedica meramente aos assuntos relacionados à manutenção da vida e suas necessidades intrínsecas (ARENDT, 2013, p. 202) que, como vimos, dizem respeito a uma dimensão particular da vida humana e não acessível ao público.

Embora ocorra em Arendt, como vimos, uma recusa ao liberalismo no tocante à separação entre liberdade e política, podemos ver, por outro lado, que a autora considera relevante a posição tradicional desta corrente de pensamento em não se permitir que a esfera pública se torne, por assim dizer, um espaço que sufoque o indivíduo. Seguindo tal perspectiva, parece-nos interessante o comentário de José Eisenberg que realça 
a marca da reflexão arendtiana em não se vincular, de modo dogmático, a nenhuma corrente de pensamento. De acordo com Eisenberg, Arendt irá privilegiar, no liberalismo, a salvaguarda de direitos que são necessários à proteção dos indivíduos e ao exercício da liberdade na república, e, por outro lado, ao se afastar de tal corrente e se aproximar do comunitarismo, ela privilegiaria o senso de pertencimento a uma comunidade. Deste modo, "nem liberal, nem comunitarista, o pensamento arendtiano caracteriza-se por duas recusas simultâneas: uma recusa radical em reduzir a singularidade do sujeito humano ao indivíduo interessado do liberalismo ou à pessoa moral do comunitarismo", e de outro lado, "uma recusa radical em reduzir a vida ativa do espaço público à vida ética da comunidade ou à vida associativa da sociedade" (EISENBERG, 2001, p. 166-167). Neste sentido, as ideias de participar do exercício do poder, de respeito aos direitos individuais e da manifestação da opinião, apenas para citar alguns elementos, afinam as perspectivas arendtianas de que uma república - nos termos que foram salientados por Canovan na relação dialética entre unidade e pluralidade - deve ser o locus profícuo para que os cidadãos construam sua comunidade e a própria cidadania.

Canovan, sobre o último tópico que mencionamos acima, nos oferece uma importante visão que às vezes pode passar desapercebida na leitura das obras de Arendt. A intérprete nos chama a atenção para o fato de que Arendt, ao refletir sobre a república, se mantém em uma tensão oscilante entre um "pessimismo sobre a capacidade dos seres humanos de estabelecer 'instituições duradouras' e otimismo diante do pensamento de que cada novo membro da raça humana é, afinal, capaz de se unir a outros para fazer um novo começo em meio às ruínas do antigo" (2002, p. 248-249) ${ }^{87}$. Nas palavras de Arendt, a tensão que foi identificada e analisada por Canovan posteriormente, pode ser expressa, ainda, nos termos de uma preocupação so-

$87 \quad[$ “(...) pessimism about the capacity of human beings to establish 'lasting institutions', and optimism at the thought that each new member of the human race is, after all, capable of joining with others to make a new beginning amid the ruins of the old."] 
bre como as leis podem harmonizar estes contrastes entre os novos começos e a perpetuação de instituições republicanas:

\begin{abstract}
No governo constitucional, as leis positivas destinam-se a erigir fronteiras e a estabelecer canais de comunicação entre os homens, cuja comunidade é continuamente posta em perigo pelos novos homens que nela nascem. A cada nascimento, um novo começo surge para o mundo, um novo mundo em potencial passa a existir. A estabilidade das leis corresponde ao constante movimento de todas as coisas humanas, um movimento que jamais pode cessar enquanto os homens nasçam e morram. As leis circunscrevem cada novo começo e, ao mesmo tempo, asseguram a sua liberdade de movimento, a potencialidade de algo inteiramente novo e imprevisível; os limites das leis positivas são para a existência política do homem o que a memória é para a sua existência histórica: garantem a preexistência de um mundo comum, a realidade de certa continuidade que transcende a duração individual de cada geração, absorve todas as novas origens e delas se alimenta (ARENDT, 1989, p. 517).
\end{abstract}

Na passagem acima a inquietação de Arendt acerca dos novos começos e da estabilidade do corpo político é evidente. A autora nos incita a concluir que as leis, no conjunto de estabilização do corpo político, são a pedra de toque para criar as possibilidades de comunicação entre os homens plurais e resguardá-los frente às incertezas da inevitável renovação do cenário público pelo nascimento político de "novos cidadãos". Isto significa dizer que na medida em que novas pessoas nascem elas se inserem na vida, porém, apenas quando se expressam no ambiente público, fazendo uso da palavra e da ação, é que se inserem "no mundo humano, e essa inserção é como um segundo nascimento, no qual confirmamos e assumimos o fato simples do nosso aparecimento físico original" (ARENDT, 2014, p. 221. Grifo nosso).

Como podemos perceber, a inscrição da natalidade na vida política é reconhecida por Arendt como algo inteiramente imprevisível, seja em um sentido de promover ações visando uma maior pungência do espaço público ou mesmo causando sua ruína. Apesar de ela não oferecer uma resposta direta para este tópico, nos importa reter a perspectiva de que é apenas preservando e cuidando do locus próprio da atividade política que os cidadãos da república podem se situar neste jogo que, ao ser desempenhado, oferece possibilidades impares no tocante a saú- 
de do corpo político, quando também demarca o tom de responsabilidade por aquele Mundo constituído e reconstituído continuamente pela política no exercício da cidadania republicana.

\section{Considerações finais}

O conceito de liberdade política é tomado como um ponto basilar dos estudos arendtianos. Buscamos mostrar, neste trabalho, que Arendt desenvolve sua perspectiva de liberdade de um modo bem demarcado, estipulando certas fronteiras conceituais com ideias relevantes da tradição filosófica ocidental. Neste sentido, o conceito de liberdade política, em Arendt, por um lado se afasta de vias que o alinhem à concepções de liberdade interior e livre arbítrio, por exemplo. Em outro sentido, ao fazer tais distinções, a liberdade política, de acordo com o que explicitamos, alimenta uma perspectiva substantiva, pois diz respeito ao que se faz e ao que se pode fazer dentro dos limites constitucionais de uma república.

Ao refletir sobre os acontecimentos nas revoluções americana e francesa, Arendt realizou a tarefa de mostrar a importância do empenho legítimo para a fundação de um corpo político. Ora, a autora, ao se preocupar com os sentidos das revoluções, elabora uma reflexão que, paulatinamente, desemboca na constatação de que uma comunidade republicana, para ser bem constituída e duradoura, deve buscar - e tal busca, no sentido de uma permanência ativa talvez seja o ponto chave da questão - a estabilização das contingências do novo em uma constituição que harmonize o espírito revolucionário de instauração de uma novidade política diante de uma comunidade que possa acolher seus cidadãos garantindo seu espaço e possibilidade de ação sem, nesse sentido, deixá-los totalmente desamparados. 


\section{Referências:}

ARENDT, Hannah. What is Freedom? In: Between past and future. Nova York: The Viking Press, 1961. p. 143-172.

ARENDT, Hannah. Sobre a revolução. Tradução Denise Bottmann. São Paulo: Companhia das Letras, 2011.

ARENDT, Hannah. Origens do Totalitarismo. Tradução Roberto Raposo. São Paulo: Companhia das Letras, 1989.

ARENDT, Hannah. Que é Liberdade? In: Entre o Passado e o Futuro. Tradução Mauro V. Barbosa. 7. ed. São Paulo: Perspectiva, 2013. p. 188-220.

ARENDT, Hannah. A Condição Humana. Tradução Roberto Raposo. Revisão técnica Adriano Correia. 11. ed. Rio de Janeiro: Forense Universitária, 2014.

ARENDT, Hannah. Ação e a busca da felicidade. In: STARLING, Heloisa. (org.). Ação e a busca da felicidade. Trad. Virginia Starling. Rio de Janeiro: Bazar do Tempo, 2018. p. 113-154.

BERLIN, Isaiah. Quatro ensaios sobre a liberdade. Trad. Wamberto H. Ferreira. Brasília: Editora UnB, 1969.

BIGNOTTO, Newton. Hannah Arendt e a Revolução Francesa. O que nos faz pensar, n. 29, p. 41-58, maio de 2011.

CARDOSO, Sérgio. Por que República? Notas sobre o ideário democrático e republicano. In: CARDOSO, Sérgio (org.). Retorno ao republicanismo. Belo Horizonte: Editora UFMG, 2004. p. 45-66.

CANOVAN, Margareth. Hannah Arendt: A Reinterpretation of Her Political Thought. Nova York: Cambridge University Press, 2002.

CONSTANT, Benjamin. Da liberdade dos antigos comparada à dos modernos. Revista Filosofia Política, n. 2, p. 1-7, 1985.

DOYLE, Willian. The Ancien Regime. Houndmills: Macmillan, 1986.

EISENBERG, José. Comunidade ou República? Hannah Arendt e as linguagens do pensamento político contemporâneo. In: BIGNOTTO, Newton; MORAES, Eduardo jardim de. (org.). Hannah Arendt: diálogos, reflexões, memórias. Belo Horizonte: Editora UFMG, 2001. p. 166-175.

KOHN, Carlos. Teoría y práctica del republicanismo cívico: La perspectiva arendtiana. Filosofía Unisinos, v. 6, n. 2, p. 138-148, mai/ ago 2005.

OLIVEIRA, José Luiz de. A fundação do corpo político no pensamento de Hannah Arendt. Tese (Doutorado) - Faculdade de Filosofia e Ciências Humanas, Universidade Federal de Minas Gerais, Belo Horizonte, 2007. 
TOCQUEVILLE, Alexis de. O antigo regime e a revolução. Trad. de Yvonne Jean. 4. ed. Brasília: Editora Universidade de Brasília, 1997. TOCQUEVILLE, Alexis. A Democracia na América: leis e costumes de certas leis e certos costumes políticos que foram naturalmente sugeridos aos americanos por seu estado social democrático. Tradução de Eduardo Brandão. Prefácio, bibliografia e cronologia François Furet. 2. ed. São Paulo: Martins Fontes, 2005. 